hat there are equally satisfactory methods of joining The employether. thographic stones is spreading and becoming mor popular. During the past autumn an exhibition was paring the metal in such a way as to enable it to take highly pleased with the specimens and results. The "algraphic" plates are used in America on rotary presse at a speed of 1,500 or 1,800 impressions per hour; at the end of a job they can be cleaned ready for fresh serplates can be employed 200 or 300 times, and if they cupied by one stone. Aluminum is at present being etc., and reports say that it is drawn over wood in this country. Some years ago it was thought that powducing the "flash light" required in many photoucing the "flash light" required in many photo graphic operations; recent exhaustive experiments,
however, go to prove that the advantages lie with inag nesiun as of yore.--The Engineer.

\section{A VISIT TO THE QUARRIES AT BEDFORD, N. Y. \\ By ALICE DINSMOR}

THE station Bedford, on the New York and Harlem Railway, with its little group of buildings near, give from the track. A mile or more away is the village with its old court house, its two or three churches, its comfortable homes, some with pillared fronts, others of inodern fashio

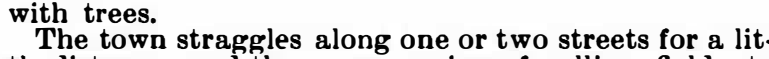
the distance, and then a succession of rolling fields to and there an outcrop of raged gneiss appears anong the trees that crown inost of these foothills of the Berkshires. With these beautiful surroundings, a rather sandy road winds up and down to the quarries
worked by Mr. Kinkel. Here a party of inembers of worked by Mr. Kinkel. Here a party of inembers of
the New York Mineralogical Club and the Mineralogy Department of the Brooklyn Institute were most kind ly entertained on Memorial Day. Quartz and feldspa which have been worked for about thirty years. Th variety rose quartz, of very rich color, is taken out in large pieces, some beautifully translucent, and great trated with black tourmaline. The president of the club identified one large black garnet that a workman had found, and sinall specimens of columbite were also annong the saine man's collection.
We saw fraginents of beryl crystals that had fallen under the blow of pick or powder, and were show where an innense crystal of beryl, weighing severa
hundred pounds, was taken out very near the surface. Manganese is represented by dendrites on fabloper. The specimens which we brought away of most in terest were autunite, its yellow.green surface at once suggestive of the uranium ores, and the very beautifu The feldspar in which the cuneiform-like bits of quartz lie is a rich flesh color. The cleavage is s qu very vivid ing ingtion to read an inseription older than any found on Assyrian monument or Egyptian Warghile the party was not fortunate enough, I be
lieve, to find any fine, perfect crystals, sone were found of great interest to the student. Annong these were
sinall, curved quartz crystals, and others showing well sinall, curved quartz crystals, and others showing well
the arrest in crystallization, three or four sides of the hexagon lying flattened on a mass of feldspar, instea hexago

Just below one of the quarries and very near the oth ers is Mr. Kinkel's mill, where he grinds the spar for inarket to crockery inakers. A "chasing mill" is used, movement than do these two ponderous stones that chase each other around a central pivot, bending a shovelful of spar thrown between them, as some monster inight crush the bones of a hapless victin. The spar all passes under two pairs of stones revolved by these it passes into an iron cylinder, about four feet in dianeter, on the floor below. The cylinder is half filled with very sinooth, dark-blue quartz, pebbles, nearly as large as hen's eggs, inported from the coast
of Norway. By the friction of the spar against these pebbles in the revolving eylinder, the complete pulverzation is accomplished, and the powder is as fine as wo finest flour. The process

Close to this inill is a kiln, where Mr. Kinkel calcines quartz when he has an order for it. He has arranged very simple and convenient device for fuel. A barrel of
oil stands on the rocks a few feet above the furnace. oil stands on the rocks a few feet above the furnace.
The oil falls through a pipe into the mouth, where a
fire of wood is first kindled; the oil is then lighted and cining it about as fast as it can be fed into the opening

above.
The woods about the quarries are very beautiful the tall oaks and chestnuts bend above most luxurian ferns of unany varieties. At the foot of the hill, acros the meadow, the Mianus flows gently along, carrying two mills, one where corn, grain, and spar are ground, the other a sawnill.

Sitting in the shade of an old orchard, beside the little river, far enough from the inills to find them rather picturesque features in the landscape, wasby. no mean bers of the party of mineralogists.

A party of Mexicans and a diamond expert of Chicago have gone to the Balsas River region of the state of Guerrero, Mexico, where they expect
inond mining on an extensive scale.

\section{LIQUID AIR}

LIQUEFACTION OF GASES. By Prof. T. O'Conor sloANe.

S65 pages. 8vo. Containing many inustrations, with portraits
of Faraday, Pictet, Cailetet. Dewar and Tripler. PRICE \$2.50.

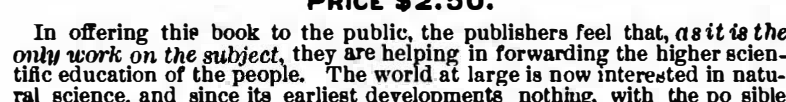
ral science, and since itt earliest derelopments nothing. with the po sible
exception of Electricity, has excited such widespread attention as Liquid Air.
toris book containg the full theory of che subject. It gives the entine his-
theefaction of gases, from the earliest times to the present, and also contains a description of all the experiments that have exected the
wonder of audiences al over the country. It shows bow liquid ain, like
water, is carried hundreds of miles and is hauded in open buckets a also

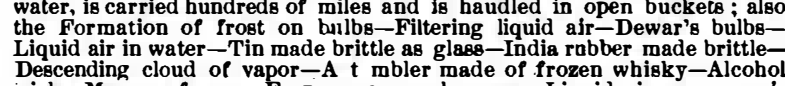

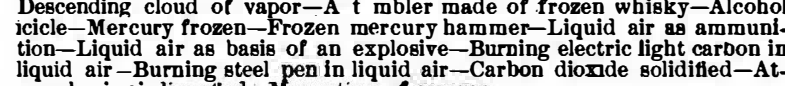
mospheric air liqueited - Magnetism of oxygen
It telle what may be

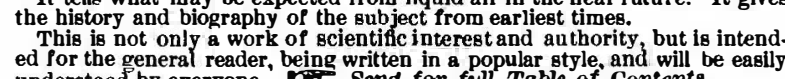
MUNN \& CO., Publishers, 361 Broadway, Now York. 1898 EDITION.

EXPERIMENTAL SCIENCE. BY GEO. M. HOPKINS.

Twentieth Edition, Revised nd Enlagred. 914 P ges. 820 Ulustr tions. Elegantly bound in Cloth. Price, by mail,

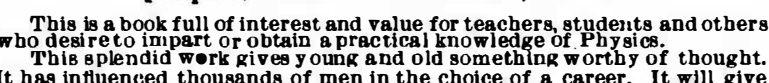

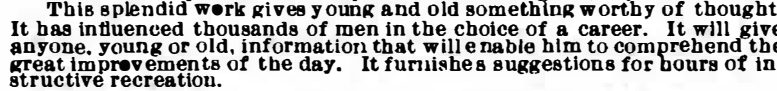

What the Press says of "Experimental Science."

"Mr. Hopkins bas rendered a valu;
able service to experimental physics."
$-E v e n$ ing Post.

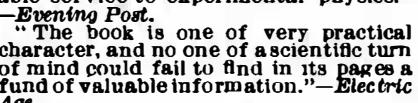

Age. The work bears the stamp of a
writer who writes nothing but with cer-

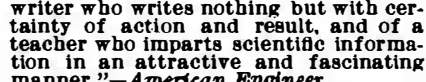

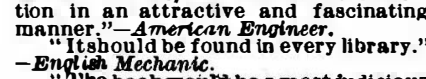

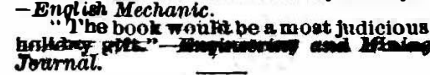

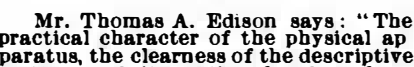

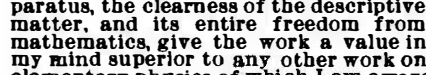

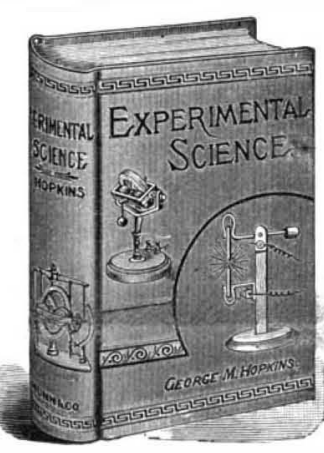

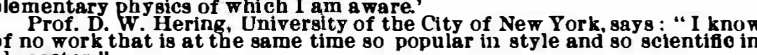

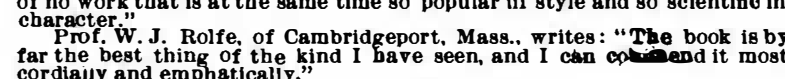

Hundreds of cordial recommendations from eminent Professors
and Scientific men.

Send for Illustrated Circular and Table of Contents.

THE SCIENTIFIC AMERICAN

CYCLOPEOIA of RECEIPTS, NOTES and QUERIES

EDITED BY ALBERT A. HOPKINS.

12,500 Receipts, 708 Pages.

Price, $\$ 5$ in cloth; $\$ 6$ in sheep; $\$ 6.50$ in half morocco; Postpaid
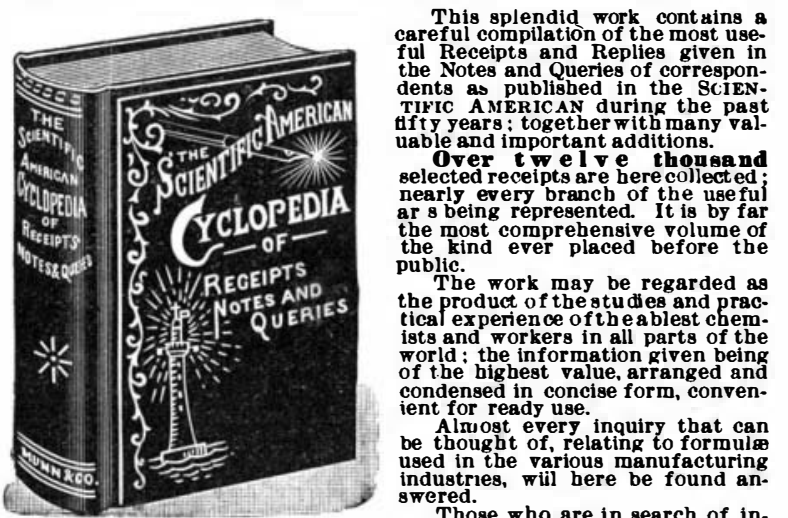

dependent business or employment, relating tose the tho are in search of in

\section{A COMPLETE}

Electrical LibRARY

BY PROF. T. O'CONOR SLOANE.

Comprising five books, as follows:

Arithmetic or Elentricity, 138 pages

Hectrie Toy Making, 140 pages......................81.00 How to Becomo n Snccempul Electrician, 189 pp. 1.00 Blectricity Simplified, 158 pages $\ldots 82$ pages.......... 3.0

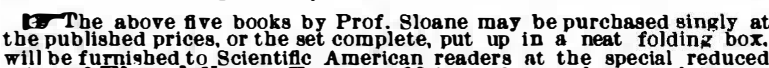

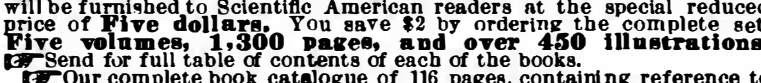

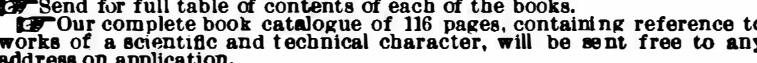

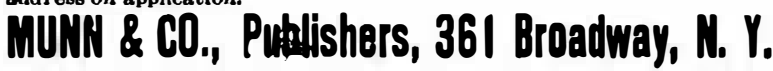

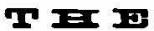

Scientific American Supplement. PUBlished WEEKLY.

Terms of Subscription, $\$ \overline{5}$ a Year.

Sent by mail, postage prepaid. to subscribers in any year. sent. prepaid, to any foreign country. Ali the back numbers of THE SUPPLEMFNT, from the
commencement. January 1, 1876, can be had. Price, 10 cents each. wise be suppiied. Two volumes are issued yearly. bound in stiff covers.

CoMbined Rates. - One copy of Scinntific AMERiCAN and one copy of SCIFNTIFIC AMERICAN SUPPLKMENT, one vear, postpaid, $\$ 7.00$.
A liberal discount to booksellers, news agents, and

MUNN \& CO., Publishera, 361 Broadway, New York. TABI,E OF CON'LEN'TS.

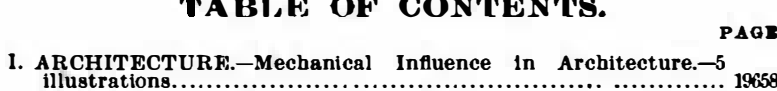

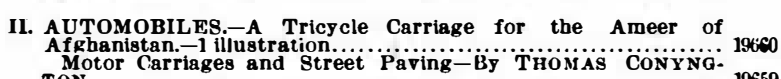
III. BOTANY AND HORTIC.............................................. 1969

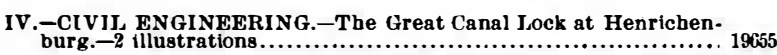
v. COMMERCE.-Trade Suggestions from United States Consuls.... 19656 VI. ELECTRICITY.-The Electric Light Bath......................... 19550

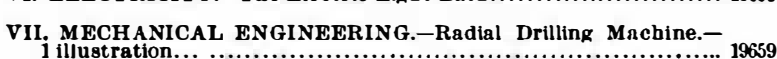

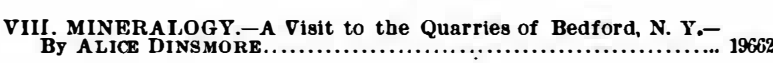
IX. MISCELLANEOUS:
EnRineering Notes:
Miscellaneous Notes
Selected

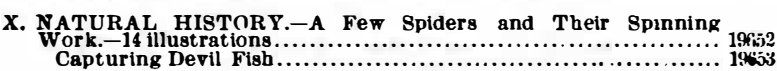
XI. PHYSICS.-Liquid Air.-By Dr. W. HAM Psos.-1 illustration...... 19650 XII. RAILROADS.-The Metropolitan Underground Kailway of XIII. TECHNOLOGY.-The Progress of Aluminum..................... 1966 XIV. TRAVEL AND EXPLORATION.-The French at Muscat.-

$==$ = SPECIAL = =

Bicycle and Automobile ISSUE OF THE

SCIENTIFIC AMERICAN

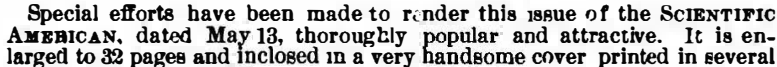

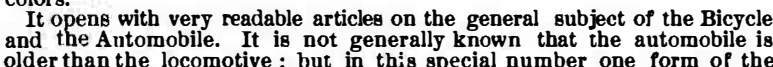

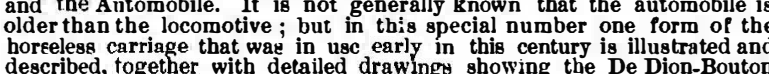
described, together with detailed drawingy showing the De Dion-Bouton
Automobole Tricglele
This is isue contains illustrated articles on the leading types of antoThis issue contains illustrated articles on the leading types of anto-
mobiles, and detailed drawing are given of one of the most successful of
the French motors. The mechanics of the bicycle are treated in an illustrated article in which the simpler tricks of bicycle riding are explaned.
Thbis number is thoroughly readable and of unusual interest to all who
are in any way interested in out-door sports.

A Beautiful Special Number-Profusely lllus-

trated-32 pages-Cover in Colors.

For sale at all news-stands. Price 10 cent MUNN \& Co., Publishers,

361 Broadway, - - - New York City。

\section{BUILDING EDITION} SCIENTIFIC AMERICAN.

Those who contemplate building should not fail to ONLY \$2.50 A YEAR.

Semi-annual bound volumes $\$ 2.00$ each, yearly bound volumes $\$ 3.50$ each, brepaia by nuail. Each number contains elevutions and
pariety of country houses; also a handsome

\section{COLORED PLATE.}

SINGLE COPIES, - - - - 25 CENTS EACH MUNN \& CO., 361 Broadway, Now York

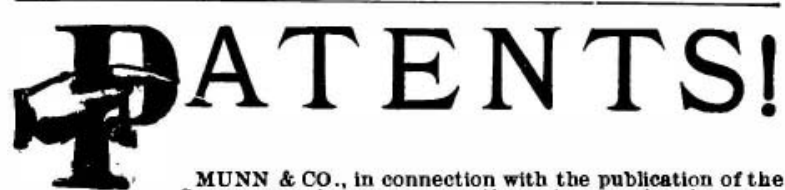

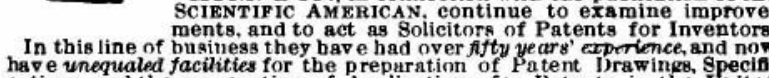

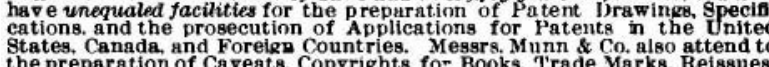

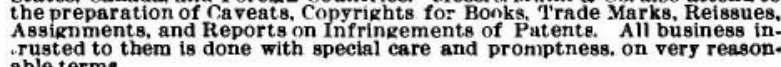

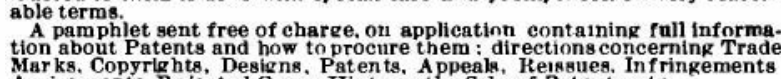

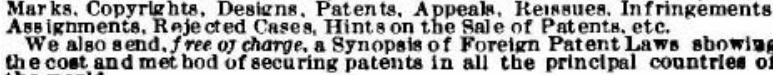
the worla MUNN \& Co.p Bolicitorn of Patents, 